\title{
Recognise what? The limitations of settler colonial constitutional reform
}

\section{Introduction}

Like other settler colonial states, Australia has struggled to reconcile its history of violent dispossession with its aspiration for peaceful, democratic legitimacy. The most recent expression of this struggle for moral legitimacy has taken the form of a political commitment — and an associated campaign — to achieve the 'recognition' of Aboriginal and Torres Strait Islander peoples in the Australian Constitution. The recognition of the Indigenous peoples of the continent in the nation's founding document is understood by many Indigenous and non-Indigenous people as an important component of Australia's 'unfinished business' of reconciliation. Legal scholar George Williams, for example, has suggested that Australia 'ought' to recognise Aboriginal and Torres Strait Islander peoples in the Constitution, that it 'does not speak well of our nation' that this has not yet happened, and that it is 'past time' that the Australian Constitution was 'founded upon equality that recognises Indigenous history and culture with pride' (Williams 2013: 14). Williams also suggests that Indigenous peoples have 'long sought' such recognition (Williams 2013:11), and with Megan Davis argues that Aboriginal and Torres Strait Islander people have argued for change to the Constitution 'since the early years after Federation' (Davis and Williams 2015: 2-3).

These views are partially correct. They may, however, be overstated. While opinion polls suggest that the majority of Australians do support the proposal to 'recognise' Indigenous peoples in the Constitution, it is not at all clear that, in the absence of a proposed model of 'recognition', Australian voters are agreed on what it is they are 
supporting. Further, and central to the concerns of this article, such polling does not reveal the diversity of views, and growing opposition, among Aboriginal and Torres Strait Islander peoples with regard to these proposals. This is of central importance given that, to have any merit at all, a recognition referendum must surely require the backing of the group being 'recognised' (Davis and Williams 2015: 135). At the time of writing, however, this is far from the case, with Aboriginal and Torres Strait Islander people feeling 'excluded' from the process in a political landscape absent of people with 'cultural authority, or even democratic legitimacy', populated instead by 'freelancers' with 'no accountability' (Davis quoted in McQuire 2016).

In light of this, this article explores the limits of the current Australian campaign for constitutional 'recognition' of Aboriginal and Torres Strait Islander peoples. Although Australia's constitutional and legal order is regarded as one of the world's most stable and popularly supported systems, this stability rests in part on what Melissa Castan (2000: 202-3) describes as some 'inherent defects' that undermine its acceptance by Indigenous people. Chief among these is the Constitution's neglect of the historical dispossession of Aboriginal and Torres Strait Islander peoples. Yet, as the campaign for constitutional recognition unfolds, the loudest dissenting voices are coming from Indigenous people themselves, many of whom insist that recognition within what they see as an illegitimate constitution will not address their claims upon the legitimacy of the nation. As Megan Davis (2016: 91) has noted, five years into the campaign for recognition Aboriginal resistance to the idea continues to grow. Thus, while it has been suggested that Indigenous recognition would 'complete' the nation, and that the failure of the campaign would be 'catastrophic for the national psyche', such arguments are, 
as Kirstie Parker (2016: 101) suggests, 'not especially persuasive among an audience who live catastrophe every day.'

This article takes these dissenting views seriously, and recommends a cautious view of the nation-building agenda driving the campaign for recognition. The article begins by considering the limitations of a nation-building approach to reconciliation, pointing to the ways in which such an approach excludes the decolonising aspirations of Indigenous peoples and drives towards closure and unity over a more open-ended agonistic engagement. It then reviews the history of reforms to the Australian Constitution and the origins of the current campaign, revealing the disappointing outcomes for Indigenous peoples, before discussing the diversity of Aboriginal and Torres Strait Islander views of the current process. The article concludes by proposing a more agonistic engagement on this issue; one that favours dissent and contestation over consensus and closure, and which aspires towards a revised constitution that remains more open to future challenge and reform.

\section{Reconciliation, national identity, and the Australian Constitution}

The campaign for recognition is generally situated along the continuum of actions undertaken in Australia thought to contribute to reconciliation between Indigenous and non-Indigenous peoples. In settler colonial societies such as Australia, both Indigenous and non-Indigenous people have turned to constitutional reform as a means of addressing historical exclusions. Indeed, as Andrew Schaap has argued (2007: 15) the process of political reconciliation may originate in an act of constitution making or constitutional reform, in which a public, the 'we' of the society, is instantiated. Paul 
Muldoon suggests that this aspect of reconciliation efforts may provide a moment in which 'questions of constitutional justice - those relating to the very foundations of the political order — take centre stage' (Muldoon 2008: 125).

Despite these ambitions, however, the national focus of constitutional reform can also be seen to reinforce the nation-building agenda of a reconciliation process, with all the problems that may bring. Indigenous peoples may understand the collectivity within which they constitute themselves as lying outside the settler state, and many emphasise their lived experience as being one of 'struggle against the dispossessing and demeaning fact of colonization by foreign peoples' (Alfred and Corntassel 2005: 597). This puts Indigenous aspirations at odds with the nation-building focus of constitutional reform. Unless the national narrative expressed in a constitution can be opened up to conflict and contestation about the place of Indigenous peoples within the nation it will inevitably contain unjust exclusions, based on the assumption that Indigenous peoples already 'belong'. While a legal constitution may have a significant role in mandating the conditions necessary for reconciliation, there is also a great risk that any legal constitution will also foreclose 'the opportunity to contest the terms within which such a relationship is determined' (Schaap 2007: 28).

At its base, a national constitution, whether written or composed of unwritten conventions, is intended to outline the body of laws, principles, institutions, and values by which a country is governed. Often this legal framework draws on the history of the country's founding. As such, a constitution is an expression of state sovereignty, including internal sovereignty or the recognition of state legitimacy to make laws for its own citizens. It is often with a focus on shoring up this sovereign legitimacy that a 
nation-building approach to reconciliation will direct attention toward processes intended to overcome past divisions and replace them with a sense of shared nationhood (Bashir and Kymlicka 2008: 14).

The Australian model of reconciliation has consistently been advanced within a framework of nation building that emphasises the need for national unity. As Damien Short (2008: 162) argues, however, this approach to reconciliation has effectively placed a 'colonial ceiling' on Indigenous aspirations. Reconciliation efforts in Australia have denied Aboriginal and Torres Strait Islander peoples the opportunity to properly pursue many of their foundational claims regarding colonial injustice, providing them with 'a right to be incorporated into the Australian nation but not a right to refuse' (Short 2005: 274). This tension is also evident in current contestation over the proposal to 'recognise' Aboriginal and Torres Strait Islander peoples in the Australian Constitution, where the assertion of a unified nationhood ignores perpetual and unresolved questions about Australia's legitimacy and sovereignty.

In spite of colonisation, many Indigenous peoples (in Australia and elsewhere) still assert their status as sovereign nations or peoples. This fact is central to an evaluation of reconciliation efforts intended (perhaps) to address the historic injustices of colonial dispossession and its contemporary legacies, as it can 'elucidate a benchmark by which to ascertain the authenticity of such a process' (Short 2005: 273). The loss of sovereignty is central to the historic injustices experienced by Indigenous peoples, and the challenge to the sovereign authority of the state has become the defining claim of the international indigenous rights movement (Jung 2011: 241). Questions of sovereignty, such as those raised by indigenous peoples in settler colonial states may 
thus create particular dilemmas for reconciliation. In such societies an emphasis on (re)inscribing a common national identity and defending the moral authority of state sovereignty may be problematic and strongly contested (Jung 2011: 242).

In light of this, this article contends that the democratic interest is better served by an agonistic engagement of diverse views, including those that may challenge national unity and legitimacy. Agonism can be understood as both a theoretical framework useful for analysing the democratic merits of the process leading towards a constitutional referendum, and as a possible model for constitutional reform itself, which might produce a more 'lively' constitution open to ongoing democratic contestation and reform (a suggestion requiring further development than is possible here, but to which I gesture in the conclusion to this article). Here the focus is on agonism as a theoretical framework that might guide or shape the 'recognition' debate.

An agonistic ambition for constitutional reform seeks to make structures of power visible in ways that enable marginalised and oppressed groups to challenge the legal and political hegemony (Wingenbach 2011: 28). Agonism enhances democratic legitimacy in two ways. First it resists the inherently exclusionary focus on rationality that underpins both majoritarian and deliberative approaches to democracy, and that tends to exclude points of view that challenge the dominant order (Maddison 2015, Little 2007,156$)$. This concern is of particular relevance in historically divided societies like Australia, in which one or more group has experienced historical exclusion and marginalisation, leaving them skeptical of ahistorical projects aimed at democratic 'inclusion' that require them to 'set aside memories of oppression and exclusion' (Bashir 2012: 132). As Iris Marion Young (2001: 41) has argued 'where structural 
inequalities influence both procedures and outcomes, democratic processes that appear to conform to norms of deliberation are usually biased toward more powerful agents.'

Second, agonism addresses a related concern about the desired outcome of more deliberative engagements. Although the deliberative focus on consensus has been considerably problematised in recent years, there is still a view that consensus supports greater stability, and is therefore views as 'an inherently positive phenomenon' (Little 2007: 144). Increasingly, however, deliberative democrats have conceded that the pursuit of consensus has the potential to become 'tyrannical' (Gutmann and Thompson 2004, 28). Agonism provides an alternate framework for engagement. As Ed Wingenbach (2011: 33) argues, 'the agonistic project emphasizes the creation of a symbolic space or regime of cultural intelligibility enabling citizens to engage in contestation without destroying the conditions of association that make community possible'. Thus an agonistic process of engagement in constitutional reform does not necessarily seek to destroy the nation's legal framework, but instead drives towards a more open-ended debate where the conditions of association are not assumed to reside within a singular sovereignty in which Indigenous people may merely be 'recognised.'

This point goes to the heart of concerns about the process of constitutional reform in the Australian context. As Wingenbach (2011: 55, my emphasis) explains, an agonistic view sees a constitution as capable of both enabling democratic contestation and as 'the ongoing product of this activity', meaning that a constitution's authority will always depend upon its capacity to sustain rather than constrain democratic activity. Constitutions are 'living codes' that derive their authority from the capacity to foster 
rather than foreclose democratic conflict over their own meanings. Wingenbach (2011: 56) suggests that democracy:

... can be considered free to the extent the rules negotiated to maintain the enterprise are subject to dissent, revision, and renegotiation, and that these rules make such agonistic engagement plausible and accessible rather than difficult and rare.

The Australian proposals to recognise Aboriginal and Torres Strait Islander peoples in the constitution are thus far falling short of this agonistic democratic threshold on two counts. First, from the outset there has been a sense of urgency driving the proposals, underscored by the view that this would be a 'once in a lifetime' opportunity, reminding us that as one of the world's most rigid constitutions the 'rules to maintain the enterprise' are rarely subject to revision or renegotiation. What this ignores is that for many Aboriginal and Torres Strait Islander people the process of constitutional reform itself is an integral part of their struggle for recognition. Second, and fuelled by this first concern, the very fact that the rules of constitutional revision in Australia are so rigid has seen debate focus on what 'might' be achievable, rather than on what many Aboriginal and Torres Strait Islander people actually want. As a result, rather than being drawn into a more agonistic public engagement, dissenting Indigenous voices have been marginalised or ignored. Instead, the process itself should prefigure any eventual reforms to the constitution, foregrounding the need for more open-ended contestation rather than succumbing to the nation-building drive for unity and closure.

\section{Constitutional reform in Australia}


The proposed 'recognition' of Aboriginal and Torres Strait Islander peoples in the Australian Constitution is seen by many as an effort to address an historical oversight. The constitution that created a federation of the former Australian colonies in 1901 gave little thought to how Indigenous peoples might be included in the new nation. There is no record of Aboriginal and Torres Strait Islander people playing any role in the drafting of the Constitution, nor was their consent sought regarding the creation of a new nation on Indigenous ancestral lands (Davis and Williams 2015: 24). In fact the only references to Aboriginal people were in Section 51 (xxvi), which empowered the federal parliament to make laws with respect to the 'people of any race, other than the aboriginal race,' and Section 127, which excluded Aboriginal people from being counted in the national census. And while neither section actually excluded Aboriginal and Torres Strait Islander people from Australian citizenship, they both suggested that Indigenous peoples were not really a part of the Australian nation (McGregor 2011: xvii-xx).

In 1967, following a ten-year campaign, Australia passed a referendum intended to address these exclusions. Significantly, the 1967 campaign had almost universal support from Aboriginal and Torres Strait Islander people, and an evident 'consensus between Indigenous groups and non-Indigenous groups' (Davis and Langton 2016: 5). The reforms in the 1967 referendum were quite modest, giving the Commonwealth government the power to make laws in relation to (although not necessarily for the benefit of) Aboriginal and Torres Strait Islander people and allowing Aboriginal and Torres Strait Islander people to be counted in the census, and were passed with the highest majority (90.77 percent) ever achieved in a referendum. In many ways, 1967 was a remarkable triumph. Yet, while the 1967 referendum did delete discriminatory 
references to Aboriginal people it put nothing in their place, meaning that rather than recognising Aboriginal and Torres Strait Islander peoples, the referendum 'left a silence' at the centre of the Constitution (Davis and Williams 2015: 4).

Further, it quickly became clear that the changes achieved in the 1967 referendum were not as transformative as many Indigenous people had hoped (Davis and Williams 2015: 47). As Kevin Gilbert argued, 'Many blacks thought that at last a new deal for black people was imminent' and their disillusionment 'hit hard' (Gilbert 2002 [1973]: 101). In the years that followed, Indigenous hopes faded that the referendum would be a step towards more transformative measures such as the recognition of Aboriginal land rights (the rejection of which by then prime minister Billy McMahon prompted the 1972 establishment of the Aboriginal Tent Embassy in Canberra), or the negotiation of a treaty (Davis and Williams 2015: 47). Thus, in 1983 a Senate Standing Committee recommended further constitutional change that would permit the negotiation of a new relationship between Indigenous peoples and the Australian state (Senate Standing Committee on Constitutional and Legal Affairs 1983). As the Treaty ' 88 campaign and the presentation of the Barunga Statement (calling for a treaty) to Prime Minister Hawke made evident, many Aboriginal and Torres Strait Islander people continued to hope that government would one day engage in a new dialogue about Indigenous peoples' relationship to the Australian nation.

The contemporary conversation about constitutional recognition was prompted by a 2007 election promise by former prime minister, John Howard, who pledged to hold such a referendum if he were re-elected. In the years since then, a referendum on constitutional recognition has become the policy of both major parties, and in 2010 the 
then prime minister, Julia Gillard, commissioned an 'Expert Panel' of Indigenous and non-Indigenous experts to undertake extensive, nation-wide consultation on the issue. The widely consultative work of the panel did a great deal to enhance the popular legitimacy of any proposed reforms. However, the drive towards national unity, rather than a more agonistic engagement, was evident from the outset. Two of the four principles adopted by the Expert Panel to guide its assessment of proposals during the consultation process emphasised the need for unity, demanding that proposals must 'contribute to a more unified and reconciled nation' and 'be capable of being supported by an overwhelming majority of Australians from across the political and social spectrums.'

The Expert Panel released its report in January 2012, recommending the repeal of two provisions in the constitution that allow racial discrimination (Section 25 and Section 51 xxvi, the 'races powers'), and the creation of a new section recognising that 'the continent and its islands now known as Australia were first occupied by Aboriginal and Torres Strait Islander peoples;' acknowledging their continuing cultures, languages, heritage, and relationship to their traditional lands and waters; and proposing that the federal parliament have powers to make laws for the 'advancement' of Aboriginal and Torres Strait Islander peoples. The Panel further proposed two additional sections prohibiting racial discrimination and providing for the recognition of Indigenous languages. Significantly, however, the Panel rejected the call from many Aboriginal and Torres Strait Islander people that a referendum should consider the 'constitutional recognition of the sovereign status of Aboriginal and Torres Strait Islander peoples' on the grounds that such a proposal 'would be highly contested by many Australians, and 
likely to jeopardise broad public support' for the reforms (Expert Panel on Constitutional Recognition of Indigenous Australians 2012: xvi, xviii).

The public face of the Expert Panel was found on the website YouMeUnity, which provided a range of information about the referendum proposals under discussion. After the release of the Panel's report, YouMeUnity was rebranded 'Recognise', and given the task of leading the campaign for a successful referendum. Indeed, rather than facilitating the engagement of diverse views, Recognise has primarily campaigned in support of a coherent national narrative. Despite the fact that a model of recognition has yet to be formally proposed, the Recognise campaign continues to push for support.. Their website communicates their task as involving 'a very specific focus', namely 'to raise awareness of the need to end the exclusion of Aboriginal and Torres Strait Islander peoples from the Australian Constitution and deal with racial discrimination in it' (Recognise n.d.).

Certainly, there is an evident degree of support for constitutional recognition among many Aboriginal and Torres Strait Islander people. A May 2015 poll, commissioned by Recognise, found that 87 percent of Aboriginal and Torres Strait Islander people surveyed would vote yes if a referendum were held today (Recognise 2015). Importantly, however the type of recognition that most often receives this support is generally described as 'meaningful', with high profile leaders and activists including Patrick Dodson, Marcia Langton, Noel Pearson, Megan Davis, and Larissa Behrendt advocating for both symbolic and substantive measures of recognition (Davis and Williams 2015: 136). As Davis and Langton (2016: 5) contend, the plea from Aboriginal and Torres Strait Islander people over the years has been: 
...to adjust Australia's constitutional arrangements so that our people can take better control of our lives and own the responsibility for our children's futures. The kind of recognition first peoples seek is one of empowerment and making space for the first peoples to play an active role in the nation.

Noel Pearson (2016: 20) contends that even the proposal from constitutional conservatives, which promises to 'guarantee the indigenous voice in indigenous affairs' would provide an opportunity to 'instigate a profound shift in the way political conversations with respect to indigenous affairs take place'. For Davis and Langton (2016: 5), the gap between this understanding of constitutional reform and the minimalist models that are suggested as a means of ensuring a successful 'Yes' vote, 'explains why the ambiguity of the word recognition has led to a dissonance between the campaign to recognise and the Aboriginal political domain'.

Over time, concerns about the exclusion of dissenting Indigenous voices from the Recognise campaign began to creep into official processes. In July 2015 , following a meeting of 40 Aboriginal and Torres Strait Islander representatives at Kirribilli House in Sydney, attending by both the Prime Minister and the Leader of the Opposition, a breakaway position was advanced by four key attendees - Patrick Dodson, Noel Pearson, Megan Davis, and Kirstie Parker - who wrote a letter to the Prime Minister requesting 'a proper Indigenous process' that would determine 'where Indigenous people stand' on the question of constitutional recognition. The proposed process involves a series of Indigenous conferences followed by a national Indigenous convention. The outcomes of the convention would then feed into broader community consultations before concluding with a diplomatic process between Indigenous representatives and political leaders intended to produce a multiparty agreement on a 
model to take to a referendum. Thus, although the Kirribillli House meeting reflected what Davis (2015a: 5) describes as the 'Indigenous middle ground' it also produced a belated acknowledgment of the need to ask those to be 'recognised' what it is that they want.

This proposal, for a so-called 'black process' was initially rejected by government, however in December 2015 it was announced that a Referendum Council would be established, including several members of the original Expert Panel, plus one of the Joint Campaign Directors of Recognise, with a view to conducting a series of regional Indigenous-only meetings, culminating in a national Aboriginal and Torres Strait Islander convention during 2016. Reflecting on this decision, Kirstie Parker (2016: 102) suggests that establishing such a process should have been undertaken at the outset of the Recognise campaign, and 'will constitute a significant amount of heavy lifting in this so-far flawed process'. This, Parker believes, 'has helped to stem growing cynicism within our community', although with a note of caution she adds '...for now'. Davis (2015a: 6), herself a member of the Referendum Council, is also cautious, observing that this process risks reducing Aboriginal and Torres Strait Islander people to a 'stakeholder position, feeding their routinely unheard aspirations through another entity outsourced with the task of deciding that which the parliament should really resolve.' Here again, we see the limits of the current process. As mere 'stakeholders Aboriginal and Torres Strait Islander people are prevented from engaging in more agonistic debate concerning their conditions of association within (or outside of) the Australian nation.

\section{Pressure, dissent, and poor process}


Davis (2016: 90-91) argues that, so far, the road to recognition has shown 'all the signs of poor process':

From 2011 to 2016, the nation funded four processes in five years. Three of these processes have had no decisive response from government and the fourth is currently in train.[...] Having a campaign before an amendment, let alone a coherent narrative of what reform is being pursued, has made it difficult for Australians, including Indigenous communities, to have a debate. It is assumed that this must be what they seek.

The resulting 'backlash against the recognition project in the Aboriginal and Torres Strait Islander community' (Davis 2015b: 1) is being driven by two concerns related to the shortcomings in the process. Both concerns directly impinge on the capacity for Australian constitutional 'recognition' to attend to a more agonistic mode of engagement.

The first issue concerns what is being experienced by many Indigenous people as a kind of 'disproportionate pressure' exerted through the view that the 'once-in-a-generation opportunity' to achieve constitutional change will only be possible if a weak form of recognition is accepted (Little and McMillan 2016). The timeline for the referendum has been both endlessly delayed (from the original proposition that a referendum be held during the term of the $43^{\text {rd }}$ parliament ${ }^{1}$ ) and now rushed, leading to feelings of

\footnotetext{
${ }^{1}$ During the 2010 federal election campaign both major parties committed to holding a referendum on the question of Indigenous recognition in the Australian Constitution. During the subsequent formation of a minority government by the Australian Labor
} 
coercion among Indigenous people, who also risk being blamed for its failure (Little and McMillan 2016: np). In the face of this pressure Davis (2015a: 5) points out that most Aboriginal and Torres Strait Islander people are waiting on a final model to be proposed before they can say how they would vote. Without a definitive model, a simplistic idea of recognition 'has been shopped around for public consumption as a no-brainer and uncontroversial', a strategy that has 'inadvertently raised the ire of a battle-weary [Indigenous] polity’ (Davis 2015b: 2). Larissa Behrendt agrees, pointing out that 'there still are a lot of questions within the Indigenous community... people, not knowing what the model is, are still a bit unsure as to whether they want to sign up to it or not' (quoted in Archibald-Binge 2016). In particular it is the pressure towards a speedy consensus among Aboriginal and Torres Strait Islander people that has led to an angry response from some.

The Recognise campaign itself is criticised for its role in the process. Described by journalist Paul Daley (2016: 3) as 'a mega-million dollar public relations campaign to promote a nebulous, ill-defined proposal' while the significant group of Indigenous people who have expressed their opposition to the Recognise campaign, discussed further below, are not in receipt of any government funding to argue their cause. Arrente writer and activist Celeste Liddle remains cynical about the fact 'that a Recognition

Party, the question of a referendum found its way into negotiations between Prime Minister Julia Gillard and the Greens and Independent Members whose support she needed in order to be able to govern, resulting in a commitment to hold a referendum 'during the 43rd Parliament or at the next election on Indigenous constitutional recognition.' 
standpoint is the only one the government deems necessary to fund' (Liddle 2015a blog). This is a point also made by Davis (2015a: 2), who finds it anomalous that there is 'a taxpayer-funded campaign to bestow settler recognition on Aboriginal and Torres Strait Islander peoples in the Constitution, while the purported subjects of that recognition are ambivalent, at best.' Davis (2015a: 3) also objects to the level of media attention directed towards the "upbeat and hyperbolic narrative of "recognition"" while, she points out, 'in the community of the recognised? *crickets*.'

It is in light of these concerns that Davis (2015a: 4) dubs much of the process to date as being one of 'gesture politics'. She points out that Aboriginal and Torres Strait Islander peoples are seeking more than recognition; they are also seeking 'institutionalised safeguards and the right to be consulted, and to participate actively in decision-making.' In the place of serious debate however Indigenous peoples are being told:

Some recognition is better than no recognition... Or worse, that symbolism is substantive reform, or that any change to the Constitution is more than symbolic; as if the natives aren't well attuned to settler semantics. When we push back, saying we are seeking reform, not non-reform, something transformative, not decorative, we are described as ambitious; the blacks are taking a hard line. They, on the other hand, routinely and unselfconsciously describe themselves as modest, considered, conservative. The presupposition in the mainstream recognition conversation, that this was only ever about symbolism, is erroneous. It is restraining any sophisticated public debate (Davis 2015a: 5 emphasis in the original). 
How these concerns with process link to concerns with the substance of recognition leads to the second major problem with the Australian campaign. Many Aboriginal and Torres Strait Islander people are worried that the pressures inherent to the nationbuilding focus of the Recognise campaign risk closing down space for a more agonistic engagement about meaningful reform. As Liddle (2015a) notes, while Recognise may listen to dissenting voices, it is explicitly not their role 'to promote Indigenous views opposing constitutional recognition, nor is their driving force the centering of Black Nationalist and/or protreaty views.' Indeed, there is some evidence to suggest that within the Recognise campaign there is a desire to close down the space for dissenting Aboriginal and Torres Strait Islander voices. Although one co-director has pointed out that many Recognise events 'have featured dissenting voices' (Gartrell 2015), a former co-director was vocal in advocating for the finalisation of the referendum question by the end of 2015 so that lead up to the suggested 2017 referendum date could be most effectively used 'to put the nitpickers and the naysayers firmly back in their armchairs' (Medhora 2015: 1).

This dismissive attitude is in contrast to a view suggesting that, as with any other issue, there is a 'wide breadth of opinion' amongst Aboriginal and Torres Strait Islander peoples, including a proportion that is 'outright opposed to any inclusion' in the constitution, and many others who are becoming 'increasingly disillusioned and cynical' (Parker 2015: 2-3). Stan Grant (2016: 2) has suggested that 'Blackfellas are sceptical at best, hostile at worst', when it comes to the Recognise campaign, with many wondering 'if it is not a con' when so many are expressing their preference for recognition of sovereignty and a treaty (that is, contesting the terms of their inclusion/non-inclusion) over recognition in the Constitution. Amy McQuire (2015b: 4) notes the extent to which 
Indigenous dissenters feel that 'a great cloak has been put over sovereignty and treaty' and suggests that despite efforts to repress these views 'There are still calls for treaty and sovereignty. They are not white noise.'

Those critical of the constitutional reform proposals also include some well known leaders and activists from the more radical end of the political spectrum, including Gary Foley and Michael Mansell, whose primary concern is that constitutional 'recognition' may in fact undermine Indigenous aspirations to achieve a treaty or treaties with the Australian state, and for broader recognition of Indigenous sovereignty (Davis and Williams 2015: 137). Many Aboriginal and Torres Strait Islander people continue to see a treaty or treaties as offering the possibility for a new framework in the settler colonial political relationship. In contrast, Mansell (2016: 47) describes the proposal for constitutional amendments as 'anti-sovereignty' because it endorses the status of Aboriginal and Torres Strait Islander peoples as 'mere citizens instead of as a distinct sovereign people,' an approach he describes as 'intellectually shallow and politically short-sighted.' Mansell dismisses the proposal to remove the races power as 'just peripheral.' Rather than tinkering with a legal framework that would still 'leave it to white politicians to decide the fate of Aboriginal people' Mansell suggests that the races power 'should be given back to the people from whom it was taken from in the first place', so that Aboriginal and Torres Strait Islander people 'have a veto over any legislation' - a far more agonistic and open-ended future than recognition would suppose. For Mansell, any question put to a referendum will still be 'implicitly endorsing the right of white people to decide our fate' while he notes that Aboriginal and Torres Strait Islander people have 'had 220 odd years to rethink that strategy' (Quoted in McQuire 2015a). 
Certainly, the fact that there is some Indigenous support for the proposed referendum does not tell the whole story. The 2015 survey data produced by Recognise has been contested, and an attempt made to refute its findings through an alternative survey published on the IndigenousX website. The IndigenousX survey was prompted by an assessment that Aboriginal and Torres Strait Islander views being expressed on social media platforms 'showed something quite different' to the Recognise survey results, and made the 87 percent figure produced by Recognise seem 'not indicative of a lot of mob discussions' and therefore 'highly questionable'. Several people involved in IndigenousX agreed that the results of the Recognise poll 'had no basis in the communities which we each knew and were a part of' (Liddle 2015b). The results of the IndigenousX survey certainly presented a different picture to that reported in the Recognise poll. Of the 824 people who responded, 25 per cent indicated support for Recognise, 58 per cent indicated that they did not support Recognise, and 17 per cent were unsure as to whether they supported Recognise or not. Only 33 percent indicated that they would vote yes even if all of the Expert Panel's recommendations were included.

Recognise were quick to defend their survey, pointing out that, unlike the IndigenousX survey, their polling had been commissioned from Polity Research, which did not practice self-selecting polls as they are considered to be 'notoriously inaccurate.' The IndigenousX survey, which was promoted through Twitter and other social media, was, according to Gartrell (2015) not only not nationally representative, but was the equivalent of 'asking your friends about an issue and then saying "everyone I have spoken to agrees with me." Gartrell maintains that Recognise has 'never denied there 
is dissent nor that there are critics of the movement' only that they 'disagree on the scale of it.' In response, Liddle points out that her analysis of the survey data acknowledges that there may be some 'skewing' of the results due to the survey method, but maintains the validity of accessing Aboriginal and Torres Strait Islander points of view through social media due to the particular characteristics of many Indigenous communities. Liddle (2015b) further suggests that there were 'no limits' to the IndigenousX survey, which Recognise could have promoted and shared through their own networks had they chosen to pursue 'an alternative means to gauge community views'. Ultimately, as Liddle (2015a) points out, the results from the IndigenousX survey make it clear that 'the discussion on this topic is far from over from an Indigenous perspective.'

Concerns about polling persist. In May 2016, during the federal election campaign, Vote Compass released results showing that 72 per cent of the 200,000 Australians who had taken the survey were in favour of recognition, answering yes to the question 'The Australian Constitution should recognise Indigenous people as Australia's first inhabitants.' The narrow focus of the questions was the subject of criticism, with Aboriginal legal scholar Larissa Behrendt pointing out that 'Indigenous participants did want to have some ability to talk about a treaty and its relationship with constitutional recognition', which she saw as 'fairly reflective of what we hear in the general community, where there is actually a push for a treaty to be there as part of the constitutional recognition debate or instead of it' (quoted in Archibald-Binge 2016). Indigenous rights barrister Tony McEvoy, also responded to the Vote Compass data by suggesting that 'many people' within Aboriginal and Torres Strait Islander communities see constitutional reform as 'a distraction from the ultimate outcome 
being a treaty.' McEvoy argues that 'At some point the treaty discussion is going to have to enter the national political debate' (quoted in Ford and Blumer 2016). Davis (2015b: 2) believes that discussion of a treaty as the 'ultimate form of recognition' will dominate discussion at the Indigenous conventions to be held by the Referendum Council during 2016, and suggests that 'rehearsed claims' of recognition as a 'stepping stone' to treaty are difficult for 'a hardened polity to stomach.' Developments in other jurisdictions suggest this is true. In February 2016300 Aboriginal Victorians met with the state government and rejected constitutional recognition in favour of negotiating a treaty - a proposition that was accepted by the Victorian Government, which is moving ahead with a negotiation process.

In the midst of these competing views it is evident that current national process has only limited merit, offering little support for the debate about a treaty or treaties that many Aboriginal and Torres Strait Islanders want. As Little and McMillan (2016) contend, what is needed is 'a more open discussion about the process itself,' including 'the topics that are on the table for discussion.' Without this discussion, regardless of how 'beautifully packaged' the recognition campaign is, as long as it seeks input only from those described by McQuire (2015c: 4) as 'a select Aboriginal elite' it will continue to be 'a white thing.' And as McQuire (2015b: 4) asks, if the campaign for recognition does not have overwhelming support from Aboriginal and Torres Strait Islander people 'what point is there to it at all?'

\section{Conclusion}


Davis and Williams (2015: vii) list five arguments against constitutional recognition including questions of political priority, cost, the stability of the current constitution, and the potential for unintended consequences that may arise from High Court interpretation. Their final point is that 'There is no agreement about how the Constitution should be changed. Even Aboriginal and Torres Strait Islander peoples have different views. Until there is unanimity, no referendum should be held.' Confidence remains that Aboriginal and Torres Strait Islander peoples will reach agreement on the way forward (Davis and Langton 2016: 25), but it has also become harder to ignore the increasing volume of dissenting Indigenous voices insisting that recognition within what they see as an illegitimate constitution will not address their claims upon the legitimacy of the nation. Indeed, where there is consensus among Aboriginal and Torres Strait Islander people it is on the grounds that 'weak' form recognition will not be enough (Davis and Langton 2016: 7). To meet the challenge raised by Indigenous assertions of their abiding sovereignty, a decolonising reconciliation process must find ways to recognise Indigenous peoples as distinct political entities that must be treated as 'nations equal in status to the settler state' (Short 2005: 276).

For this possibility to be realised, however, there is an urgent need to rethink the process by which such a position is reached. Davis and Langton (2016: 5) are seemingly in favour of a more agonistic process, suggesting that the Australian political system 'is one that respects difference and can mediate disagreement', and arguing that Aboriginal and Torres Strait Islander people could use the Referendum Council process and the subsequent campaign to 'engage in a deep conversation with Australians about our shared future.' Indeed, until this kind of engagement is possible, there can be no 
meaningful process towards constitutional recognition. The fact that a 'yes' vote might succeed regardless of Indigenous dissent and discontent would, as Little and McMillan (2016) point out, indicate 'the failure of constitutional recognition to transform relations in Australian society.'

Such an unsatisfactory outcome need not be a foregone conclusion. But for the promise of recognition to be realised there must be several significant changes to the process. The first must be a concerted and public effort to acknowledge dissenting Indigenous views and welcome them into a more agonistic public engagement on the future relationship between Aboriginal and Torres Strait Islander peoples at the state. The second must be to concede that other options, most notably the negotiation of a treaty, may be preferred options among Aboriginal and Torres Strait Islander communities.

The third is a more radical, if very preliminary, proposition, but one that I believe has some merit: rather than considering a referendum on constitutional recognition to be a 'once in a lifetime proposition' we could contemplate a more 'lively' constitution, which reviews the status of the relationship between Indigenous peoples and the Australian state on a regular basis. To include some kind of sunset clause ensuring that achieving 'recognition' would not close down the space for future debate about sovereignty and treaty, and acknowledged that recognition would not resolve the status of the legal and political relationship between Aboriginal and Torres Strait Islanders people and the state, would allow for a more agonistic constitution in the terms imagined by Wingenbach (2011). 
An agonistic view of democratic institutions acknowledges that ongoing effort is required to disrupt their tendency towards sedimentation (Wingenbach 2011: 97). Certainly, many Aboriginal and Torres Strait Islander people have expressed the view that they are tired of having their political lives conducted according to timelines dictated by the settler order. In this sense, a democratic constitution might involve a looser agreement, one that is able to be periodically revisited, and enough only for disparate groups to agree to be governed in common while still contesting the terms of their association (Wingenbach 2011: 34). Aboriginal and Torres Strait Islander peoples in Australia are historically, geographically, linguistically, and culturally diverse, and the complexity of determining governance arrangements that are satisfactory to all should not be underestimated. Further research to determine what a more open structure to political cohesion might look like, could examine whether such a structure would provide enough space for an agonistic politics of reconciliation to develop, despite the demographic dominance of the settler order. Such a structure may enable the negotiation of multiple treaties between Indigenous peoples and the Australian state. Observing the ongoing treaty-negotiation process in Victoria may provide lessons for other jurisdictions in this regard, as only time will tell as to whether this process will allow the political pressures of an election cycle to foreclose the negotiations, or whether a more open-ended process may be possible.

One assessment would suggest that the current effort to reform the Australian Constitution should be a productive and democratic exercise. At this point, however, it seems that the campaign for recognition is directed towards the further stabilisation of a sense of national unity. This is not necessary. National identities can take the form of an ongoing 'conversation' that can accommodate profound disagreements without 
fracturing a commonality built on earlier conversation and a continued commitment to engage (Webber 2000: 79). At this point in time, however, the very real risk is that Aboriginal and Torres Strait Islander people involved in this conversation will not be heard, a fact that will only cause ongoing anger and despair (Davis 2016: 96).

\section{References}

Archibald-Binge, Ella. 2016. Community needs more clarity on recognition: Larissa

Behrendt. SBS NITV News, 20 May. URL: <http://www.sbs.com.au/nitv/nitvnews/article/2016/05/20/community-needs-more-clarity-recognition-larissabehrendt>. Consulted 21 May 2016.

Bashir, Bashir \& Kymlicka, Will. 2008. Introduction: Struggles for inclusion and reconciliation in modern democracies. In B. Bashir and W. Kymilicka, eds. The politics of reconciliation in multicultural societies. Oxford: Oxford University Press.

Castan, Melissa. 2000. Reconciliation, law and the Constitution. In M. Grattan, ed. Reconciliation: Essays on Australian Reconciliation. Melbourne: Black Inc.

Daley, Paul. 2016. We'll never close the gap until we start again with Indigenous policy. The Guardian, 3 February. URL: <http://www.theguardian.com/australianews/postcolonial-blog/2016/feb/09/well-never-close-the-gap-until-we-start-againwith-indigenous-policy?CMP=share_btn_tw>. Consulted 5 February 2016. 
Davis, Megan. 2016. Ships that pass in the night. In M. Davis and M. Langton, eds. It's our country: Indigenous arguments for meaningful constitutional recognition and reform. Melbourne: Melbourne University Press.

Davis, Megan. 2015a. Gesture politics: Recognition alone won't fix indigenous affairs. The Monthly, December. URL:

<https://www.themonthly.com.au/issue/2015/december/1448888400/megandavis/gesture-politics>. Consulted 5 February 2016.

Davis, Megan. 2015b. Keating was right to intervene over recognition and Indigenous Australia's unfinished business. The Guardian. 21 October. URL:

http://www.theguardian.com/commentisfree/2015/oct/21/soft-recognition-alone-willnot-resolve-indigenous-australias-unfinished-business>.

Davis, Megan and Langton, Marcia. 2016. Introduction. In M. Davis and M. Langton, eds. It's our country: Indigenous arguments for meaningful constitutional recognition and reform. Melbourne: Melbourne University Press.

Davis, Megan and Williams, George. 2015. Everything you need to know about the referendum to recognise Indigenous Australians. Sydney: NewSouth Publishing.

Dodson, Patrick. 2000. Beyond the Mourning Gate: Dealing with Unfinished Business, AIATSIS, The Wentworth Lecture 12 May 2000, National Gallery of Australia. 
Expert Panel on Constitutional Recognition of Indigenous Australians. 2012.

Recognising Aboriginal and Torres Strait Islander Peoples in the Constitution:

Report of the Expert Panel, Canberra.

Gartrell, Tim. 2015. We all have a responsibility to listen. Recognise website, 1 July.

URL: <http://www.recognise.org.au/blogs/polling/>. Consulted 15 August 2015.

Gilbert, Kevin. 2002 [1973]. Because a white man'll never do it, A + R Classics, Sydney: Harper Collins Publishers.

Grant, Stan. 2016. I don't have all the answers, but we need to find a narrative that speaks to non-Indigenous Australia. The Guardian, 26 January. URL:

<http://www.theguardian.com/commentisfree/2016/jan/27/i-dont-have-all-theanswers-but-we-need-to-find-a-narrative-that-speaks-to-non-indigenous-australia> . Consulted 5 February 2016.

Jung, Courtney. 2011. Canada and the legacy of the Indian residential schools: Transitional justice for indigenous people in a nontransitional society. In P. Arthur ed., Identities in transition: Challenges for transitional justice in divided societies, New York: Cambridge University Press.

Liddle, Celeste. 2015a. 87\% of Indigenous people do not agree on recognition. You'd know if you listened. The Guardian, 19 June. URL: <http://www.theguardian.com/commentisfree/2015/jun/19/87-of-indigenous-people- 
do-not-agree-on-recognition-youd-know-if-you-listened>. Consulted 15 August 2015.

Liddle, Celeste. 2015b. Recognise: Their response to the IndigenousX survey, and my response to some misrepresentations. Rantings of an Aboriginal Feminist blog, 30 June. URL: <http://blackfeministranter.blogspot.com.au/2015/06/recognise-theirresponse-to-indigenousx.html>. Consulted 15 August 2015.

Little, Adrian and McMillan, Mark. 2016. On the wrong track: Why Australia’s attempt at Indigenous reconciliation will fail. The Conversation, 20 May. URL: $<$ https://theconversation.com/on-the-wrong-track-why-australias-attempt-atindigenous-reconciliation-will-fail-58064>. Consulted 21 May.

Little, Adrian. 2007. Between disagreement and consensus: Unravelling the democratic paradox, Australian Journal of Political Science, 42(1): 143-159.

McGregor, Russell. 2011. Indifferent inclusion: Aboriginal people and the Australian nation. Canberra: Aboriginal Studies Press.

McQuire, Amy. 2016. Without a model backed by Aboriginal communities, what are we actually 'Recognising'? New Matilda, 11 August. URL: https://newmatilda.com/2016/08/11/the-timing-of-a-recognise-referendum-isnot-what-matters/. Consulted 12 August 2016.

McQuire, Amy. 2015a. Recognise cracks deepen as Tasmanian leader says referendum won't bring justice. New Matilda, 15 April. URL: 
<https://newmatilda.com//2015/04/15/recognise-cracks-deepen-tasmanian-leadersays-referendum-wont-bring-justice>. Consulted 15 August 2015.

McQuire, Amy. (2015b), Recognise: The debate that is failing and dividing Black Australia. New Matilda, 5 March. URL:

<https://newmatilda.com/2015/03/05/recognise-debate-failing-and-dividing-blackaustralia>. Consulted 15 August 2015.

McQuire, Amy. 2015c. The farce at Kirribilli: Abbott, Shorten put the con back into constitutional reform. New Matilda, 7 July. URL:

<https://newmatilda.com/2015/07/07/farce-kirribilli-abbott-shorten-put-con-backconstitutional-reform/> Consulted 15 August 2015.

Medhora, Shalailah. 2015. Indigenous recognition: Parties told compromise on key referendum question. The Guardian, 12 June. URL:

<http://www.theguardian.com/australia-news/2015/jun/12/indigenous-recognitionparties-told-compromise-key-on-referendum-question>. Consulted 15 August 2015.

Maddison, Sarah. 2015. Conflict transformation and reconciliation: Multi-level challenges in deeply divided societies, London: Routledge.

Mansell, Michael. 2016. Is the Constitution a better tool than simple legislation to advance the cause of Aboriginal peoples? In M. Davis and M. Langton, eds. It's our country: Indigenous arguments for meaningful constitutional recognition and reform. Melbourne: Melbourne University Press. 
Muldoon, Paul. 2008. The very basis of civility: On agonism, conquest, and reconciliation. In B. Bashir \& W. Kymilicka eds. The politics of reconciliation in multicultural societies. Oxford: Oxford University Press.

Parker, Kirstie. 2015. Is Indigenous constitutional recognition salvageable? We have to hope so. The Guardian, 20 April. URL:

<http://www.theguardian.com/commentisfree/2015/apr/20/is-indigenousconstitutional-recognition-salvageable-we-have-to-hope-so?CMP=share_btn_fb>. Consulted 15 August 2015.

Parker, Kirstie. 2016. Building a new, better legacy. In M. Davis and M. Langton, eds. It's our country: Indigenous arguments for meaningful constitutional recognition and reform. Melbourne: Melbourne University Press.

Pearson, Noel. 2016. Foreword. In Freeman Damien and Morris Shireen eds. The forgotten people: Liberal and conservative approaches to recognising Indigenous peoples. Melbourne: Melbourne University Press.

Recognise. N.d. What is Recognise? URL: <http://www.recognise.org.au/about/whatis-recognise/>. Consulted 15 August 2015.

Recognise. 2015. Ready to recognise: An overwhelming 'Yes' if vote held today. Media release. 18 May. URL: <http://www.recognise.org.au/wpcontent/uploads/2015/05/5.-MR-ReadyToRecognise18May2015.pdf>. Consulted 15 
August 2015.

Schaap, Andrew. 2007. The time of reconciliation and the space of politic. In S.

Veitch ed. Law and the Politics of Reconciliation. Aldershot: Ashgate.

Short, Damien. 2008. Reconciliation and colonial power: Indigenous rights in Australia, Aldershot: Ashgate.

Short, Damien. 2005. Reconciliation and the problem of internal colonisation. Journal of Intercultural studies 26(3): 267-282.

Webber, Jeremy. 2000. Beyond regret: Mabo’s implications for Australian constitutionalism. In D. Ivison, P. Patton \& W. Sanders, eds., Political theory and the rights of Indigenous peoples. New York: Cambridge University Press.

Wingenbach, Ed. 2011. Institutionalizing agonistic democracy: Post-foundationalism and political liberalism, Farnham: Ashgate.

Young, Iris Marion, 2001. Activist challenges to deliberative democracy. Philosophy of Education yearbook, 41-55. 


\section{University Library}

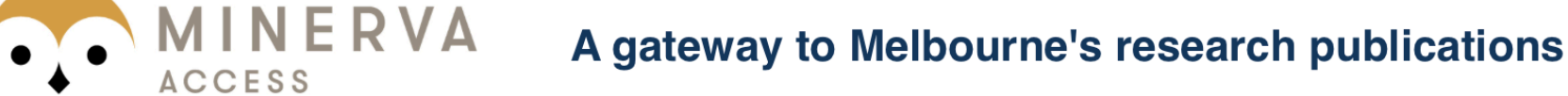

Minerva Access is the Institutional Repository of The University of Melbourne

Author/s:

Maddison, $S$

Title:

Recognise what? The limitations of settler colonial constitutional reform

Date:

2017-03-01

Citation:

Maddison, S. (2017). Recognise what? The limitations of settler colonial constitutional reform. AUSTRALIAN JOURNAL OF POLITICAL SCIENCE, 52 (1), pp.3-18. https:// doi.org/10.1080/10361146.2016.1260684.

Persistent Link:

http://hdl.handle.net/11343/292084 